International Journal of Canadian Studies

Revue internationale d'études canadiennes

\title{
The Relationship between Professional Immigrant Parents' Underemployment Status and their Children's Emotional Health and Behavioral Patterns
}

\author{
Iraj M. Poureslami, Clyde Hertzman, Libby Hattersley et Laura Nimmon
}

Numéro 42, 2010

Canadian Issues: childhoods, states, nationalisms

Enjeux canadiens : enfances, États, nationalismes

URI : https://id.erudit.org/iderudit/1002169ar

DOI : https://doi.org/10.7202/1002169ar

Aller au sommaire du numéro

Éditeur(s)

Conseil international d'études canadiennes

ISSN

1180-3991 (imprimé)

1923-5291 (numérique)

Découvrir la revue

Citer cet article

Poureslami, I. M., Hertzman, C., Hattersley, L. \& Nimmon, L. (2010). The Relationship between Professional Immigrant Parents' Underemployment Status and their Children's Emotional Health and Behavioral Patterns. International Journal of Canadian Studies / Revue internationale d'études canadiennes, (42), 9-24. https://doi.org/10.7202/1002169ar
Résumé de l'article

Cette étude porte sur la relation entre une vie stressante et le faible statut économique des immigrants professionnels en sous-emploi dans la région de Vancouver (RV) et la santé émotionnelle et comportementale de leurs enfants. La population cible a participé à des entretiens et à des discussions de groupe basés sur une méthode qualitative transversale. De plus, des groupes de consultation ont été mis sur pied avec des organismes de services aux immigrants (intervenants clés). Les résultats ont été analysés en fonction de la situation d'emploi des participants et de leur pays et région d'origine. Les participants sous-employés ont rapporté un taux de santé et de satisfaction à l'égard de la vie plus faible pour eux-mêmes et leur famille, des relations familiales plus houleuses, ainsi que davantage de structures émotionnelles et de modèles comportementaux défavorables chez leurs enfants. Les participants originaires de l'Asie du Sud-Est sont ceux qui ont déclaré les niveaux les plus élevés de sous-emploi et de présence de structures émotionnelles et de modèles comportementaux défavorables chez leurs enfants, tandis que les participants de l'Europe de l'Est ont obtenu les taux les plus faibles pour ces mêmes catégories. Ces résultats ont permis d'étayer et d'approfondir les théories existantes portant sur la corrélation entre le sous-emploi, le dysfonctionnement familial et la présence de problèmes émotionnels et comportementaux chez les enfants.
All Rights Reserved @ Conseil international d'études canadiennes, 2010

Ce document est protégé par la loi sur le droit d'auteur. L'utilisation des services d'Érudit (y compris la reproduction) est assujettie à sa politique d'utilisation que vous pouvez consulter en ligne.

https://apropos.erudit.org/fr/usagers/politique-dutilisation/ 


\title{
Iraj Poureslami, Clyde Hertzman, Libby Hattersley and Laura Nimmon
}

\section{The Relationship between Professional Immigrant Parents' Underemployment Status and their Children's Emotional Health and Behavioral Patterns}

\begin{abstract}
This study examined the relationship between a stressful life and low economical status due to underemployment among professional immigrants in the Greater Vancouver Area (GVA), and their children's emotional and behavioural health. Employing a cross-sectional qualitative design, interviews and focus groups were conducted with the target population, and focus groups were held with representatives from immigrant service-provider agencies (key-informants). Findings were analysed according to participants' employment status and country/region of origin. Underemployed participants reported the lowest levels of life satisfaction and health status for themselves and their families, the poorest family relationships and the most unfavourable emotional and behavioural patterns for their children. Southeast Asian participants reported the highest rates of underemployment and unfavourable child emotional and behavioural patterns, while the lowest rates in both categories were seen among Eastern European participants. Thefindingssupportedandexpandedexistingknowledgeofthelinks between underemployment, family dysfunction, and poor child emotional and behavioural outcomes.
\end{abstract}

\section{Résumé}

Cette étude porte sur la relation entre une vie stressante et le faible statut économique des immigrants professionnels en sous-emploi dans la région de Vancouver (RV) et la santé émotionnelle et comportementale de leurs enfants. La population cible a participé à des entretiens et à des discussions de groupe basés sur une méthode qualitative transversale. De plus, des groupes de consultation ont été mis sur pied avec des organismes de services aux immigrants (intervenants clés). Les résultats ont été analysés en fonction de la situation d'emploi des participants et de leur pays et région d'origine. Les participants sous-employés ont rapporté un taux de santé et de satisfaction à l'égard de la vie plus faible pour eux-mêmes et leur famille, des relations familiales plus houleuses, ainsi que davantage de structures émotionnelles et de modèles comportementaux défavorables chez leurs enfants. Les participants originaires de l'Asie du Sud-Est sont ceux qui ont déclaré les niveaux les plus élevés de sous-emploi et de présence de structures émotionnelles et 
de modèles comportementaux défavorables chez leurs enfants, tandis que les participants de l'Europe de l'Est ont obtenu les taux les plus faibles pour ces mêmes catégories. Ces résultats ont permis d'étayer et d'approfondir les théories existantes portant sur la corrélation entre le sous-emploi, le dysfonctionnement familial et la présence de problèmes émotionnels et comportementaux chez les enfants.

\section{Background}

Canada is host to a large number of highly-educated professional immigrants (Krahn et al; Austin and Este) and this number has increased considerably over the past three decades, from $22.24 \%$ in the 1970 s to $40.71 \%$ in the 1990s (Dunn and Dyck; Citizenship and Immigration Canada, 2002). These immigrants come to Canada to start a new life and hope that their education and professional experience will give them the opportunity to earn salaries commensurate with their years of education. The literature shows, however, that these newcomers face much greater difficulty in finding jobs relevant to their training than those born in Canada (Botchford; Krahn and Lowe; Statistics Canada, 2003; Statistics Canada, 2004; Beiser et al; Hum and Simpson). Many newcomers, therefore, end up either unemployed as they struggle to upgrade their education to match Canadian standards, or choosing different careers or jobs totally unrelated to their professional training, thereby being 'underemployed' (Krahn et al; Austin and Este; Statistics Canada, 2003a; Statistics Canada, 2004; Beiser et al; Gray et al). This underutilization of immigrant skills may be understood as any employment of immigrants in work below a level of skill at which they could function as effectively as native-born Canadians (Reitz, 2001). Unemployment/ underemployment and their consequences i.e., low income and a stressful life (Kazemipur and Halli; McDonald and Worswick), have been shown to be associated with physical and mental health problems (Hammarstrom and Janlert; Murray et al; Bjarnason and Sigurardottir; Pederson and Mads; Winefield, 1995; Fryer and Winefield; Catalano, 1991, Hammarstrom and Janlert), and significant disparities in health and social status exist between the un/underemployed and their family members, and the general population (Arrow; Madge; Christoffersen).

Worldwide, there is growing recognition that research into the employment status of professional immigrants and its impact on children's health status is important (Arrow; Austin and Este; Tai-Ann et al; Rodriguez; Kumar; Beiser), and many studies in developed countries have examined the health consequences of joblessness and unemployment among immigrants and their families (Arrow; Winefield, 2002; Derks et al; Jones; De-Lange et al; Chandrasena et al; Linn et al; Trovato; Jahoda; Baum et al; Ensminger and Celentano). In Canada, much effort has been made to study the impact of family income on children's health and quality of life in the general population (Curtis et al - Krahn et al; - Dunn and Dyck). There have been fewer 
attempts to address such effects among immigrant families however, and until now, no study examining the links between parents' underemployment status and children's health among families of professional immigrants in Canada has been reported. In general, researchers have pointed out that there is a dearth of research that examines the impact of underemployment on health (Feldman et al; Friedland and Price; Dooley and Prause).

The aim of this study was to examine the relationship between stressful life and low economic status due to underemployment among professional immigrants in the Greater Vancouver Area (GVA), and their children's emotional and behavioural health. In order to conduct the study, the project team partnered with a number of immigrant service provider agencies in the Greater Vancouver Area (the Canadian Multicultural Health Promotion Society, Vancouver Coastal Health Services, Afghan Canadian Women's Network, S.U.C.C.E.S.S., MOSAIC and SOLUTIONS).

\section{Methods}

The project employed a cross-sectional, qualitative and quantitative study design, using a combination of primary research techniques (focus groups and in-depth interviews). The study sample was selected using non-random, purposeful sampling from lists provided by partnering service provider agencies, as well as through community networks. The target population for this study was adult professional immigrants (over 21 years of age) from South Korea, Chinese, India, Iran, Afghanistan, and Russia living in the GVA. The primary rationale for selecting these particular ethnic groups was that they are among the fastest growing immigrant communities in British Columbia (BC), accounting for $36 \%$ of professional immigrants landed in Canada between 1996-2002 (Citizenship and Immigration Canada, 2002; Citizenship and Immigration Canada, 2000; Statistics Canada, 2003b). Furthermore, they were chosen to include both visible and non-visible (i.e. of Non-European and European origin) minority groups in the study. The non-visible group was intended to serve as a limited form of control for analyzing ethnicity discrimination (Catalano, 1991; Greater Vancouver Regional District; Mulvihill et al; Curtis et al). Participants were also required to have at least one child between the ages of three and eighteen years, have lived in Canada for less than ten years, and be able to speak a level of English sufficient to be employed in an English-speaking workplace in BC.

In the first phase of the study, in-depth interviews were conducted with 110 samples from the target community during the summer and fall of 2004. Interview locations were selected by participants, and were primarily held at the participant's home. The interviews were approximately 60 minutes in length and were audio-taped. The interviews and data transcriptions were carried out by individuals from the same ethnic community as participants 
and were introduced to the study by the partner service provider agencies. The semi-structured questionnaire applied in the interviews was developed using a multi-stage process including initial testing for face and content validity using an expert panel and pilot testing for construct validity (readability, acceptability, cultural sensitivity) with a sample of 10 individuals from the target population. Behavioural questions adapted from Achenbach scales (Beiser et al; Kobayashi et al) were applied as a supplement to the interview instrument to collect relevant information about children's emotional health and behavioural patterns. Data on family income was collected using the Canada Low Income Cut-Off (LICO) scales (Curtis et al).

The second phase of the study involved two facilitated focus groups, conducted in the fall of 2004. The first focus group involved six participants from phase one of the study who had volunteered to attend the session. The second focus group involved fifteen representatives from the project's partnering immigrant service provider agencies throughout $\mathrm{BC}$.

In this paper, only key quantitative findings from the community interviews are reported and discussed. Questionnaire data was analysed using SPSS and involved simple univariate analyses and cross-tabulations. A Path Analysis model was employed to examine any associations among variables, individually and collectively. ANOVA and T-Test analyses were applied to identify significant differences among and between the parametric variables.

\section{Key Findings}

Data from 109 interviews was analyzed according to each participant's selfreported employment status (employed, unemployed or underemployed) and region of origin (South Asia (Iran, Afghanistan, and India), Southeast Asia (South Korea and Chinese) and Eastern Europe (Russia)). Interviews were conducted with 33 participants from South Asia, 59 from Southeast Asia, and 17 from Eastern Europe. Eighty-nine percent of participants were married and $85 \%$ reported using English as the primary language at work. Mean years of post-high school education among participants was 5.8 years (with a range of $1-18$ years and a mode of 6 years), and mean years of education in Canada (following immigration) was 1.7 years (with a range of 6 months 9 years and a mode of 1 year). Nineteen percent of participants held medical or health-related qualifications (i.e. physician, nurse, and other healthcare professionals), $26 \%$ held engineering-related degrees, $31 \%$ were in a teaching profession (i.e. university professor, school teacher), $12 \%$ held a science degree, and $12 \%$ were in a management field.

Forty-one percent of participants reported themselves to be underemployed at the time of the study, $44 \%$ as unemployed, and $15 \%$ as employed in a job relevant to their professional training. More than half (58\%) of participants from Southeast Asia reported being underemployed, while 35\% of 
participants from South Asia and 25\% from Eastern Europe reported themselves to be in the same category.

Overall, $57 \%$ of employed and underemployed participants reported being unsatisfied with their current job, with participants from Eastern Europe being significantly more likely to be satisfied with their current job (29\%) than participants from South and Southeast Asia (15\% and 16\% respectively). Almost one fifth (19\%) of all participants indicated that they felt unsatisfied with their life in Canada, while 57\% reported that they were somewhat satisfied, and 23\% felt very satisfied. Participants from Southeast Asia were least likely to feel satisfied with their current life in Canada, with only $9 \%$ indicating they were satisfied (compared to $30 \%$ of participants from South Asia and 29\% from Eastern Europe). Underemployed participants were the least likely to feel 'very satisfied' with their life in Canada (only $2 \%$, compared to $31 \%$ of employed and $35 \%$ of unemployed participants).

Overall, $26 \%$ of participants believed that their spouses were very satisfied with their life in Canada, $21 \%$ believed that they were not satisfied at all, and $53 \%$ felt that their spouses were somewhat satisfied with their current life in Canada. At the same time, only $10 \%$ of underemployed participants believed that their spouses were very satisfied with their life in Canada, compared to $42 \%$ of employed and $19 \%$ of unemployed participants. Fiftyfour percent of all participants believed that their first-born child was very satisfied with his/her life, $34 \%$ that he/she was somewhat satisfied and $12 \%$ felt that their first child was not at all satisfied with his/her life. Eighteen percent of underemployed participants believed that their first-born child was not at all satisfied with his/her life, compared to $0 \%$ of employed participants and $12 \%$ of unemployed participants. In addition, while $79 \%$ of employed participants believed that their first-born child was very satisfied with his/her life, only $54 \%$ of underemployed and $47 \%$ of unemployed participants felt the same way.

Table 1. First-born child's life satisfaction (as reported by parent) based on participant's employment status

\begin{tabular}{|l|c|c|c|c|c|c|c|c|}
\hline \multirow{2}{*}{$\begin{array}{l}\text { Child's Life } \\
\text { Satisfaction }\end{array}$} & \multicolumn{9}{|c|}{ Participant's Employment Status } \\
\cline { 2 - 10 } & \multicolumn{2}{|c|}{ Employed } & Underemployed & \multicolumn{2}{c|}{ Unemployed } & \multicolumn{2}{c|}{ Total } \\
\cline { 2 - 10 } & Number & $\mathbf{\%}$ & Number & $\mathbf{\%}$ & Number & $\mathbf{\%}$ & Number & $\%$ \\
\hline Very satisfied & 11 & 79.0 & 21 & 54.0 & 21 & 47.0 & 53 & 54.1 \\
\hline Somewhat satisfied & 3 & 21.0 & 11 & 28.0 & 19 & 42.0 & 33 & 33.7 \\
\hline Not at all & 0 & 00.0 & 7 & 18.0 & 5 & 11.0 & 12 & 12.2 \\
\hline Total & $\mathbf{1 4}$ & $\mathbf{1 0 0}$ & $\mathbf{3 9}$ & $\mathbf{1 0 0}$ & $\mathbf{4 5}$ & $\mathbf{1 0 0}$ & $\mathbf{9 8}$ & $\mathbf{1 0 0}$ \\
\hline
\end{tabular}

When asked about the condition of their family relationships after coming to Canada, $25 \%$ of participants believed that their family's relationships were excellent, $44 \%$ considered them to be good, and $11 \%$ to be poor. 
Underemployed participants were least likely to believe that their family relationships were excellent (15\%, compared to $31 \%$ of employed and $33 \%$ of unemployed participants), and most likely to believe that their family relationships were poor $(15 \%$, compared to $0 \%$ of employed and $11 \%$ of unemployed participants). Participants from Eastern Europe were most likely to report having excellent family relationships (41\%, compared to $0 \%$ of Southeast Asian and $36 \%$ of South Asian participants), while participants from Southeast Asia were most likely to report poor family relationships $(27 \%$, compared to $4 \%$ of South Asian and $0 \%$ of Eastern European participants).

Fourteen percent of participants reported their own health status to be excellent, $24 \%$ as very good, $50 \%$ as good and $13 \%$ as either poor or very poor. Underemployed participants were least likely to indicate excellent health status ( $7 \%$, compared to $25 \%$ of employed and $15 \%$ of unemployed participants). With respect to their families, $9 \%$ of all participants believed their spouse's health was in excellent condition and $18 \%$ believed it was either poor or very poor. In addition, $26 \%$ of all participants believed their first-born child's health status to be excellent, $22 \%$ to be very good and $2 \%$ indicated that their first child's health status was very poor. Only $12 \%$ of underemployed participants indicated their first-born child's health status to be excellent, compared to $38 \%$ of employed and $35 \%$ of unemployed participants. In addition, $10 \%$ of underemployed participants indicated that their first-born child's health status was poor (compared to $0 \%$ of employed and $8 \%$ of unemployed participants).

During the second stage of the interview, participants were asked short questions relating to 44 different behavioural and emotional variables (adopted from Achenbach's scales) (Offord and Lipman; Tremblay et al) in order to determine the frequency at which each emotional and/or behavioral pattern is exhibited by their first-born child. Participants were asked to respond to each question with one of three answers: 'never or not true', 'somewhat or sometimes true", and 'often or very true'. For the purposes of this paper only statistically significant differences are discussed and reported as single variables.

Participants who were employed were significantly more likely than unemployed or underemployed participants to report favourable emotional and behavioural patterns from their first-born children according to a number of variables. For example, $81 \%$ of employed participants reported that their child often helps others (compared to $38 \%$ of underemployed and $50 \%$ of unemployed participants), and $0 \%$ reported that their child was often distracted or physically attacks people, while $10 \%$ of underemployed participants reported that their child was often distracted, and 5\% reported that their child physically attacked people. Overall, participants from Southeast Asia reported significantly poorer emotional and behavioural patterns from 
their first-born children than South Asian and Eastern European participants. For example, only $18 \%$ of Southeast Asian participants reported that their child often shows sympathy for others, compared to $57 \%$ of South Asian and $60 \%$ of Eastern European participants. In addition, 21\% of Southeast Asian participants indicated that their child was often sad or depressed and $27 \%$ indicated that their child cried a lot, compared to $9 \%$ and $8 \%$ respectively for the two variables among South Asian participants and $6 \%$ for both variables among Eastern European participants. Furthermore, 21\% of Southeast Asian participants reported that their child was disobedient at school, compared to $2 \%$ of South Asian and $0 \%$ of Eastern European participants. These data, according to region of origin, are displayed in Table 3.

Table 2. Relationship between child's emotional and behavioural patterns and participant's employment status

\begin{tabular}{|l|c|c|c|c|c|c|c|c|c|}
\hline \multirow{2}{*}{$\begin{array}{l}\text { Child's emotional \& } \\
\text { behavioral pattern }\end{array}$} & \multicolumn{9}{|c|}{ Participant's Employment Status } \\
\cline { 2 - 12 } & \multicolumn{3}{|c|}{ Employed } & \multicolumn{3}{c|}{ Underemployed } & \multicolumn{3}{c|}{ Unemployed } \\
\hline Helps others & 6 & 13 & 81 & 24 & 38 & 38 & 13 & 35 & 50 \\
\hline Volunteers to help & 6 & 38 & 56 & 38 & 43 & 19 & 37 & 33 & 28 \\
\hline Is Distracted & 87 & 13 & 0 & 40 & 50 & 10 & 46 & 41 & 13 \\
\hline Is impulsive & 81 & 19 & 0 & 31 & 48 & 21 & 33 & 54 & 13 \\
\hline Is rather solitary & 56 & 31 & 13 & 19 & 31 & 48 & 35 & 26 & 33 \\
\hline Physically attacks people & 100 & 0 & 0 & 83 & 14 & 5 & 85 & 11 & 2 \\
\hline Gives up easily & 81 & 19 & 0 & 41 & 41 & 19 & 41 & 28 & 26 \\
\hline Is nervous & 81 & 19 & 0 & 33 & 55 & 12 & 54 & 24 & 22 \\
\hline
\end{tabular}

Key: $\mathrm{N}=$ never or not true

$\mathrm{S}=$ somewhat or sometimes true

$\mathrm{O}=$ often or very true 
Table 3. Relationship between child's emotional and behavioural patterns and participant's country of origin

\begin{tabular}{|c|c|c|c|c|c|c|c|c|c|}
\hline \multirow{3}{*}{$\begin{array}{l}\text { Child's emotional \& } \\
\text { behavioral pattern }\end{array}$} & \multicolumn{9}{|c|}{ Country of Origin } \\
\hline & \multicolumn{3}{|c|}{ South-East Asia } & \multicolumn{3}{|c|}{ South Asia } & \multicolumn{3}{|c|}{ Eastern Europe } \\
\hline & N (\%) & $\mathrm{S}(\%)$ & O (\%) & N (\%) & S (\%) & O (\%) & N (\%) & $\mathrm{S}(\%)$ & O (\%) \\
\hline Shows Sympathy & 27 & 55 & 18 & 7 & 36 & 57 & 17 & 17 & 60 \\
\hline Destroys things & 70 & 21 & 9 & 91 & 9 & 0 & 76 & 12 & 12 \\
\hline Helps others & 33 & 43 & 24 & 12 & 26 & 62 & 6 & 29 & 65 \\
\hline Is Sad/Depressed & 27 & 52 & 21 & 45 & 46 & 9 & 76 & 17 & 6 \\
\hline Is Unhappy & 30 & 43 & 27 & 56 & 30 & 14 & 65 & 17 & 17 \\
\hline Destroys things & 73 & 15 & 12 & 90 & 8 & 2 & 82 & 12 & 6 \\
\hline Is disobedient at school & 55 & 24 & 21 & 80 & 15 & 2 & 77 & 23 & 0 \\
\hline Helps others & 43 & 33 & 24 & 10 & 19 & 71 & 6 & 35 & 59 \\
\hline Is worried & 12 & 67 & 18 & 44 & 46 & 10 & 53 & 23 & 24 \\
\hline Is rather solitary & 9 & 27 & 64 & 39 & 32 & 29 & 53 & 17 & 6 \\
\hline Comforts others & 40 & 45 & 15 & 15 & 19 & 66 & 12 & 12 & 65 \\
\hline Cries a lot & 30 & 43 & 27 & 63 & 29 & 8 & 59 & 35 & 6 \\
\hline Vandalizes & 73 & 24 & 3 & 96 & 4 & 0 & 82 & 12 & 6 \\
\hline $\begin{array}{l}\text { Helps to pick up objects } \\
\text { somebody has dropped }\end{array}$ & 55 & 33 & 12 & 29 & 27 & 44 & 24 & 29 & 41 \\
\hline Appears miserable & 33 & 43 & 24 & 68 & 22 & 10 & 76 & 12 & 12 \\
\hline Is nervous & 21 & 49 & 30 & 59 & 32 & 9 & 71 & 17 & 12 \\
\hline $\begin{array}{l}\text { Invite others } \\
\text { to join in a game }\end{array}$ & 76 & 9 & 15 & 19 & 17 & 64 & 12 & 0 & 88 \\
\hline $\begin{array}{l}\text { Has trouble enjoying } \\
\text { Him/herself }\end{array}$ & 30 & 61 & 9 & 61 & 37 & 2 & 82 & 12 & 6 \\
\hline
\end{tabular}

Key: $\mathrm{N}=$ never or not true

$\mathrm{S}=$ somewhat or sometimes true

$\mathrm{O}=$ often or very true

\section{Discussion and Conclusions}

Underemployed participants in this study reported lower levels of life satisfaction and health status overall than their 'employed' and 'unemployed' counterparts. These findings support the results of other studies already reported in the literature (Dunn and Dyck; Austin and Este), In addition, underemployed participants were least likely to believe that their spouses and children had a high level of life satisfaction, least likely to consider the condition of their family relationships as excellent, (and conversely, most likely to consider the condition of their family relationships as poor), and least likely to report favourable health status of their first-born child. These results support and expand on existing knowledge regarding the serious adverse 
effects of immigrant underemployment on health and quality of life at both the individual and family levels (Krahn et al; McDonald and Worswick; Gray et al). In terms of child emotional and behavioural health, underemployed participants reported unfavourable emotional and behavioural patterns among their children with noticeably greater frequency than their employed and unemployed counterparts, and these findings are cause for concern.

Also important to note were the variations in responses between participants from the three regions of origin, and particularly between visible and non-visible ethnic immigrant groups. For example, the proportion of Southeast Asian participants (visible minorities) who were underemployed at the time of the study was more than double (58\% versus $25 \%$ ) the number of participants from Eastern Europe (non-visible minorities) in the same category. Participants from South Asia (also visible minorities) ranked in between, with $35 \%$ self-reporting as being underemployed. In addition, participants from Eastern Europe were almost twice as likely to report being satisfied with their current job than participants from South and Southeast Asia (29\% versus $15 \%$ and $16 \%$ respectively). While almost a third of immigrants from South Asia and Eastern Europe were satisfied with their life in Canada, less than 10\% of Southeast Asians felt the same way. Furthermore, participants from Eastern Europe were most likely to report having an excellent family relationship, while participants from Southeast Asia were most likely to report having a poor family relationship. When completing the child behavioural scale, participants from Southeast Asia reported significantly worse emotional and behavioural patterns from their first-born child than South Asian and Eastern European participants.

There are a number of plausible explanations for these differences. It is possible that non-visible immigrants from Eastern Europe face less discrimination from potential employers than visible immigrants from South and Southeast Asia. Immigrants who have faced significant challenges and hardship in their home countries (conceivable among immigrants from Eastern Europe and South Asia) are potentially more determined to succeed in Canada, more likely to report being satisfied with their new life, less likely to feel homesick for their country of origin, and less likely to have difficulty settling in Canada. Furthermore, ease of acculturation into Canada may differ between ethnic groups. That is, it is possible that immigrants from Eastern Europe may find it easier to adapt to Canadian customs and norms, while immigrants from Southeast Asia may have more difficulty adapting their home culture to the Canadian context. Finally, differences in socio-cultural norms between the countries of origin focused on in this study may also have influenced the findings. For example, it is practice in certain cultures to portray only excellent health and family relationships regardless of whether this is the reality or not, as a means of 'saving face' (i.e. avoiding shame and/or embarrassment). 
Regardless, the observed differences in responses between participants in this study from the three regions of origin, and between visible and nonvisible immigrants, in terms of successful integration into Canadian society, are sufficient to highlight this as an important area for future investigation. We, therefore, need to address socially related issues that might explain possible reasons for employment difficulties; such as isolation in minority occupational enclaves and the fact that minority group social networks lack the linkages necessary to find good jobs (Reitz \& Banerjee).

This study revealed a number of limitations relating to the Achenbach's Scale applied during the interviews. The impact of cultural beliefs and practices, lack of understanding of the terminology used in the scales, and irrelevancy of some items were the major issues identified by the participants. For example, it is the practice in certain cultures for parents to praise their children profusely around other people, while conversely in other cultures it is more common for parents to constantly criticize and find fault with their children. In this study, participants from Southeast Asia reported noticeably worse emotional and behavioural patterns from their first-born children than South Asian and Eastern European participants. Interestingly, South Asian participants reported lower rates of underemployment and higher levels of life satisfaction, as well as substantially better family relationships than their Southeast Asian counterparts. In addition, while Southeast Asian participants reported the highest rates of underemployment, lowest levels of life satisfaction, and poorest family relationships, they reported favourable emotional and behavioural patterns among their first-born children, at levels similar to those reported by Eastern European participants (who reported the highest rates of employment success, highest levels of life satisfaction and the best family relationships). Thus it seems plausible that there is a cultural norm among South Korean and Chinese families to criticize children heavily, while Southeast Asian parents may be more likely to praise their children highly to outsiders as a means of 'saving face'.

As the behavioural scale used did not include a "not sure" column, interviewers felt that some participants may have tried to guess their children's behaviours in an effort to record something in each column. In addition, among those families in which one parent, frequently observed to be the father, is seldom home due to work commitments, and hence has little opportunity to get to know his children's behaviours, it is plausible that this parent may have tried to 'guess' his children's behaviours. Finally, while English language ability sufficient for employment in an English-speaking workplace was a selection criterion for participation in this study, it is possible that the terminology and variables used in the behavioural scale may have been misunderstood by some participants, misinterpreted by some interviewers, and/or may be irrelevant to the child-rearing practices of some cultures. 
In summary, findings from this study support existing knowledge of the links between underemployment, poor mental well-being and family dysfunction. The results also begin to shed light on a critical issue until now poorly addressed in Canada: the association between professional immigrants' underemployment status and their children's health and well-being. Further research needs to be undertaken to investigate this area in greater depth. In addition, in light of the limitations highlighted in this study relating to the Achenbach's Scale, a culturally-competent tool for measuring the impact of parents' employment status on children's health and behaviour among ethnocultural communities should be developed. Furthermore, it is recommended that immediate actions be taken in Canada to address employment status among professional immigrants, an issue which has enormous social, economic and health consequences, not only for immigrant populations but for Canadian society as a whole.

As Canada's immigration rates increase in the context of the knowledge economy and declining employment outcomes for immigrants, the sustainability of the immigration program in the evolving global labour market is in question (Reitz, 2005). At the community level, immigrants already settled into Canada should, as a community, more actively support and assist newly arriving immigrant families. Opportunities include community support groups and networks, advocacy for additional funding and support from local businesses, institutions and government, and the provision of networking advice and assistance to newcomers. Community gatherings and events, religious and spiritual sites, and parent-teacher gatherings and other school events provide opportunities for raising awareness about immigration, stress management and family issues in Canada. Service providers, operating as the link between immigrant communities, labour markets and the government, should continuously foster and improve these links, advocating for improved labour market access for professional immigrants from both government and private employers, and providing targeted assistance and support to the various sub groups among newcomer families. Local government has an important role to play in this issue and should reassess current policies relating to professional immigrants in light of new understandings of the reality this group faces in the settlement and adaptation process. It should be acknowledged, however, that local levels of government often have the least amount of policy development, taxation power and political influence. In spite of the fact that municipalities do share much of the responsibility since they provide the services. However, they are resource poor and the metropolitan areas in which immigrants settle are not organized for joint planning (Reitz, 2005). Therefore, in addition to proposing improved funding supplied directly to service providers working with immigrant communities at the grassroots level, governments should move towards improving recognition of foreign credentials and training, and volunteerism. 
The federal government could also do more to direct highly skilled immigrants to provinces and regions where there is a need for their specific skills, and recognise their foreign qualifications and experience, thus filling essential jobs as well as enabling new immigrants to work in their area of professional expertise profession in which they are trained (Martin Prosperity Insights). Another practical way to fill specific skills gaps could be to provide some form of bridge training such as occupation-specific programs involving collaboration among educational institutions, governments and regulating bodies (Reitz, 2005). Western University, for example, currently has a successful bridging program in medical competency assessment (Easby). In addition, subsidized workplace internship and mentoring programs for immigrants might help speed the process of skills accreditation (Silkowska-Masior \& Szajkowski; Reitz, 2005). Of issue, however, is that no one Canadian government agency has clear responsibility for immigrant skill utilization, and there is often a lack of intergovernmental collaboration and cooperation. Accordingly, this responsibility resides with different levels of government and with different agencies at different levels of government. It is reported that at the federal level, for example, Citizenship and Immigration Canada is responsible for immigration, and it has voiced concerns about immigrant skill utilization. Yet, paradoxically, current immigration policy is designed to minimize government involvement in matters related to the integration of immigrants into the labour force (Reitz, 2005). Clearly, government leadership will be required to coordinate the various institutional players that share the responsibility for the various aspects of the utilization of immigrants' skills. This involves the federal government for immigration and for broad economic and social policy, the provincial governments for employment, education and municipal affairs, and municipal governments for immigrant settlement and delivery of services (Reitz, 2005). In summary, the federal government needs to be challenged to live up to its ideals of plurality, equality, and tolerance. Given the economic, social and public health aspects that emerged in this study's findings, helping to rapidly settle and integrate professional immigrants and their families is one of the biggest challenges Canada will face in an evolving global labour market.

\section{Acknowledgements}

We would like to thank all of our community and service-provider partners in the Greater Vancouver Area for their contributions to this project.

\section{Works Cited}

Arrow JO: Estimating the influence of health as a risk factor on unemployment: A survival analysis of employment durations for workers surveyed in the German socio-economic panel. Social Science \& Medicine 1996; 42(12): 1651-1659.

Austin C, Este D: The working experiences of underemployed immigrant and refugee men. Canadian Social Work Review 2001; 18(2): 213-229. 
Baum A, Fleming R, Reddy DM: Unemployment stress: loss of control, reactance and learned helplessness. Social Science and Medicine 1986; 22(5): 509-16.

Beiser M, Hou F, Hyman I, Tousignant M: Poverty, family process, and the mental health of immigrant children in Canada. American Journal of Public Health 2002; 92(2): 220-227.

Beiser M: Poverty, family process, and the mental health of immigrant children in Canada. American Journal of Public Health 2002; 92(2): 220-227.

Bjarnason T, Sigurardottir TJ: Psychological distress during unemployment and beyond: Social support and marital deprivation among youth in six northern European countries. Social Science \& Medicine 2003; 56(5): 973-986.

Botchford J: Are we letting brains waste? The Toronto Sun; December 27 2002: 69.

Catalano R: The health effects of economic insecurity. American Journal of Public Health 1999; 81(9): 1148-1152.

Chandrasena R, Beddage V, Fernando ML: Suicide among immigrant psychiatric patients in Canada. British Journal of Psychiatry 1991; 159: 707-709.

Christoffersen MN: A follow-up study of long-term effects of unemployment on children: loss of self-esteem and self-destructive behavior among adolescents. Childhood 1994; 4: 213-20.

Citizenship and Immigration Canada: Facts and Figures 2002: Immigration Overview.

Citizenship and Immigration Canada: Recent immigrants in metropolitan areas: A comparative portrait based on the 1996 census. Informetrica Limited; 2001. Accessed at http://www.cic.gc.ca/ english/research/papers/menu-recent. html\#1996

Citizenship and Immigration Canada: Recent immigrants in the Vancouver Metropolitan Area: A comparative portrait based on the 1996 Census. Informetrica Limited; 2000. Accessed at: http:/www.cic.gc.ca/english/research/ papers/1996-vancouver.html .

Curtis LJ, Dooley MD, Lipman EL, Feeny DH. The role of permanent income and family structure in the determination of child health in Canada. Health Economics 2001; 10(4): 287-302.

De-Lange AH, Taris TW, Kompier MA, Houtman IL, Bongers PM: Effects of stable and changing demand-control histories on worker health. Scandinavian Journal of Work, Environment and Health 2002; 28(2): 94-108.

Derks A, Elchardus M, Glorieux I, Pellariaux K: The effect of fathers' unemployment on school careers and values of children. In: De Goede MPM, de Kiaver PM, Van Ophem JAC, Verhaar CHA, de Vries A, eds. Youth: Unemployment, identity and policy. Aldershot: Avebury; 1996: 87-106.

Dooley, D., \& Prause, J. The social costs of underemployment: Inadequate employment as disguised unemployment. New York, NY: Cambridge University Press; 2004.Dunn JR, Dyck I: Social determinants of health in Canada's immigrant population: Results from the National Population Health Survey. Social Science \& Medicine 2000; 51: 1573-1593.

Easby, A. Immigrants underemployed. The Gazette 2009. Accessed at http://www.westerngazette.ca/2009/11/30/immigrants-underemployed/

Ensminger ME, Celentano DD: Unemployment and psychiatric distress: social resources and coping. Social Science and Medicine 1988; 27(3): 239-47. 
Feldman, D. C., Leana, C. R., \& Bolino, M. C. Underemployment and relative deprivation among re-employed executives. Journal of Occupational and Organizational Psychology 2002; 75: 453-471.

Friedland, D. S., \& Price, R. H. Underemployment: Consequences for the health and well-being of workers. American Journal of Community Psychology 2003; 32(1-2): 33-45.

Fryer DM, Winefield, AH: Employment stress and unemployment distress as two varieties of labor market induced psychological strain: An explanatory framework. Australian Journal of Social Research 1998; 5(1): 3-18.

Gray D, Mills J, Zandvakili S: Immigration, assimilation and inequality of income distribution in Canada. Journal of Economic Literature 2002; 10: 1-21.

Greater Vancouver Regional District: Research Project on Homelessness in Greater Vancouver. Jim Woodward \& Associates Inc; 2002.

Hammarstrom A, Janlert U: Nervous and depressive symptoms in a longitudinal study of youth unemployment--selection or exposure? Journal of Adolescence 1997; 20(3): 293-305.

Hum D, Simpson W: Wage opportunities for visible minorities in Canada. Canadian Public Policy 1999; 25(3): 379-385.

Jahoda M: Employment and unemployment: a social psychological analysis. Cambridge: Cambridge University Press; 1982.

Jones L: Unemployment and child abuse. Families in Society: The Journal of Contemporary Human Services 1990; 71: 579-88.

Kazemipur A, Halli S: The invisible barrier: Neighbourhood poverty and integration of immigrants in Canada. Journal of International Migration and Integration 2000; 1(1): 85-100.

Kobayashi A, Moore E, Rosenberg M: Healthy immigrant children: A demographic and geographic analysis. Hull, Quebec: Human Resources Development Canada, Applied Research Branch Strategic Policy; 1998.

Krahn $\mathrm{H}$ and Lowe GS: Work, industry and Canadian society ( $\left.3^{\text {rd }} \mathrm{ed}\right)$. Toronto: ITP Nelson; 1998.

Krahn H, Derwing T, Mulder M, Wilkinson L: Educated and underemployed: Refugee integration into the Canadian labor market. Journal of International Migration and Integration 2000; 42(3): 36-54.

Kumar V: Poverty and inequality in the UK: The effects on children. London: National Children's Bureau; 1993.

Linn MW, Sandifer R, Stein S: Effects of unemployment on mental and physical health. American Journal of Public Health 1985; 75(5): 502-506.

Madge N: Unemployment and its effects on children. Journal of Child Psychology and Psychiatry, and Allied Disciplines 1983; 24: 311-19.

Madsen M: Children's health upon entering school in Denmark, 1988/1989. Copenhagen: National Institute of Health; 1991.

Martin Prosperity Insights. Recent immigrants are the most educated and yet underemployed in the Canadian labour force 2009. Accessed at http://www. martinprosperity.org/insights/insight/recent-immigrants-are-the-most-educatedand-yet-underemployed-in-the-canadian-labour-force 
McDonald JT, Worswick C: Unemployment incidence of immigrant men in Canada. Canadian Public Policy 1997; 23(4): 353-373.

Mulvihill MN, Mailloux L, Atkin W: Advancing policy and research responses to immigrant and refugee women's health in Canada. The Centres of Excellence in Women's Health. Winnipeg, Manitoba: Canadian Women's Health Network; 2001.

Murray CL, Gien L, Solberg SM: A comparison of the mental health of employed and unemployed women in the context of a massive layoff. Women and Health 2003; 37(2): 55-73.

Offord D, Lipman EL. Emotion and behavioural problems. In: Growing up in Canada: National Longitudinal Survey of Children and Youth (NLSCY). 1996; 119-126.

Pedersen CR, Mads M: Parents' labor market participation as a predictor of children health and well-being: a comparative study in five Nordic countries. Journal of Epidemiology \& Community Health, 2002; 56(11): 8-30.

Quantz D, Frankish J: Homelessness research in the greater Vancouver regional district: An agenda for moving forward. Institute of Health Promotion Research, University of British Columbia; 2002.

Rasmussen M: Survey of schoolchildren's health in Denmark, 1998. Danish Committee for Health Education; 2001.

Reitz, J. Immigrant skill utilization in the Canadian labour market: Implications of human capital research. Journal of International Migration and Integration 2001; 2(3): 347-378.

Reitz, J. Tapping immigrants' skills: New directions for Canadian immigration policy in the knowledge economy. IRPP Choices 2005; 11(1): 1-18.

Reitz, J., and Banerjee, R: Racial inequality, social cohesion and policy issues in Canada. In: Banting K, Courchene T, Seidle L, eds. Belonging? Diversity, recognition, and shared citizenship in Canada. Montréal: Institute for Research on Public Policy 2007; 1-57.

Rodriguez E: Keeping the unemployed healthy: The effect of means-tested and entitlement benefits in Britain, Germany, and the United States. American Journal of Public Health 2001; 91(9): 1403-1411.

Schwefel D: Unemployment, health and health services: Results of German unemployment research. Strasbourg: Council of Europe; 1984.

Silkowska-Masior, B., \& Szajkowski, T. Mentorship program for new Canadians. Ottawa: Caledon Institute of Social Policy; 1998.

Statistics Canada: Immigrants setting for less? 1991-2001. The Daily; June 2004.

Statistics Canada: Longitudinal Survey of immigrants to Canada, 2001. The DailyStatistics Canada; 2003.

Statistics Canada: Low-income rates among immigrants: 1980-2000. The Daily; June 2003.

Tai-Ann Chen A, Chang J: Mental health aspects of culture and migration. Current Opinion in Psychiatry 1999; 12(2): 217-222.

Tremblay RE, Boulerice B, Harden PW, McDuff P, Pihl RO, Zoccolillo M. Do children in Canada become more aggressive as they approach adolescence? In: Growing up in Canada: National Longitudinal Survey of Children and Youth (NLSCY). 1996; 127-137. 
Trovato F: Suicide and ethnic factors in Canada. International Journal of Social Psychiatry 1986; 32: 55-64.

Vergara AE, Miller JM, Martin DR, Cookson ST: A survey of refugee health assessments in the United States. Journal of Immigrant Health 2003; 5(2): 67-73.

Winefield AH: Unemployment, underemployment, occupational stress and psychological well-being. Australian Journal of Management 2002; 27(2): 137-150.

Winefield AH: Unemployment: Its psychological costs. In: Cooper CL, Robertson IT, eds. International Review of Industrial and Organizational Psychology. Wiley: London; 1995: 169-212. 